\title{
Vol. 2: The Excellence of Technical Vocational Education and Training (TVET) Institutions in Korea: Case Study on Busan National Mechanical Technical High School
}

\author{
Lan $\mathrm{Joo}^{1}$ \\ ${ }^{1}$ The World Bank, Washington D.C., USA \\ Correspondence: Lan Joo, The World Bank, Washington D.C., USA. Tel: 1-571-337-7117. E-mail: \\ lanjoolan@yahoo.com
}

Received: May 12, 2018

Accepted: August 30, $2018 \quad$ Online Published: October 29, 2018

doi:10.5539/ies.v11n11p69

URL: https://doi.org/10.5539/ies.v11n11p69

\begin{abstract}
This study is a series of the empirical study, the Excellence of Technical Vocational Education and Training (TVET) Institutions, which has investigated the association between four premise factors (competent teachers, relevant curricula, effective leadership, and school-industry linkages) and school performance. The purpose of the study is to provide recommendations to individual institutions who seek to develop strategies to improve their internal and external efficiencies as well as provide policy makers with empirical evidence to help develop new TVET policies that increase schools' responsiveness to industry demands and reduce skills gap. The study assessed (1) whether or not the select school Busan National Mechanical Technical High School (BMT) possesses four premise factors; (2) how these factors contribute to the enhancement of school outcomes, and (3) which factor has the most influence in differing contexts (e.g. TVET policy, labor market conditions, social demands) and times. The selection criterion was the school's high graduate employment rate. The study gathered data via multiple resources, including school publications, survey, and interviews. As for the survey, 555 out of 600 students and 107 out of 113 teachers responded. The interview was conducted with 10 students, 10 specialty teachers, the principal, and one vice principal. The interview style was an in-person, one-on-one with structured, open-ended questions, where each interviewee was sequestered separately in a closed room for 60 minutes. After coding the raw data, certain themes emerged. The findings suggest that BMT possesses all the stated premise factors, and the factors directly or indirectly influence the graduate employment rate via the enhancement of employability. Additionally, the most influential factor can be altered based upon various contexts and times.
\end{abstract}

Keywords: employability, school-industry linkages, skills mismatching, TVET curricula, TVET leadership, TVET policy, TVET school reform, TVET teachers

\section{Introduction}

Due to rapid changes in technology, skills mismatching has become an emergent issue at the national level, as it has limited the country's competitiveness and economic growth. There has been dynamic discussion among TVET policy makers and educators on how to reduce skills mismatching, with the most predominant suggestion to restructure the TVET system to become more demand-driven. Therefore, TVET schools have been forced to move forward with structural changes to their teaching methods, course curricula, management practices, and industry collaboration.

Korea is not an exception to this rule. It had directly experienced the ill effects of skills mismatching and shortages, especially among youth, so its government restructured its secondary TVET system. To be specific, the government rebranded TVET schools as specialized high schools that help shape students into young professionals with specialized skills; in addition, a special purpose vocational school model is the government-developed Meister high school that helps equip youth with high-demand industrial skills, with particular focus on the technical and mechanical career fields.

This study examines the case of one Meister high school, BMT, by assessing the association between four areas (teachers, curricula, leadership, and school-industry linkages) and school outcomes (graduate employment rate). This study's methodology parallels that of Yeungjin College's case study which indicates that if a school with a high graduate employment rate possesses the suggested factors (competent teachers, relevant curricula, effective 
leadership, and school-industry linkages), then we could conclude that these factors are likely to enhance school performance. Based on the findings drawn from in-depth interviews, the study provides suggestions to individual institutions who seek to develop strategies to improve their school's internal and external efficiencies as well as provides policy makers with empirical evidence to help develop new TVET policies that increase schools' responsiveness to industry demands and reduce skills gap.

\subsection{Korean Secondary Educational System and Meister High Schools}

According to the Decree of the Elementary and Secondary Education Act of 2010, the Korean secondary educational system is divided into three types: general and autonomous high schools (academic programming); specialized high schools (TVET programming); and special purpose high schools (subject-specific programming to include science and technology, foreign language, art, etc.). Among these high schools, TVET providers are all specialized and Meister high schools (Note: Meister high schools fall under the special purpose category).

In Korea's case, the educational system has been closely linked to the country's economic policy: for example, TVET's secondary system was expanded and fortified during the 1970s to reflect the government's emphasis on the heavy-chemical industry. According to the study conducted by the Korea Development Institute School during that period, "vocational high schools played a pivotal role in pushing forward with the heavy-chemical industry, and manpower policy, including vocational high school policy, also played a critical role in supporting industrial policy" (Lee \& Hong, 2014, p. 26).

Nevertheless, since 2000 and the rapid changes in job skills requirements, companies have expressed concerns regarding the difficulty in securing adequately skilled workers. This is evidenced by the study conducted by the Small and Medium Business Administration (SMBA) (2008) that Small and Medium Enterprises (SMEs), which hire $86 \%$ of the total labor force in Korea, have faced labor force shortages, especially mid-level technicians who are supplied by TVET high schools. According to the study, the labor shortage of SMEs is approximately $7.4 \%$ (Park, 2014, p. 31).

In 2010, the government issued a major policy change to the TVET system in order to respond to the shortage of technical skilled workers and the stigma attached to TVET schools. The government rebranded TVET schools as 'specialized high schools' that emphasize specialized and sector-led courses in advantageous career fields in relation to the local economy. For example, Busan Tourism High School offers food and hospitality programs to help provide young, adequately trained professionals to the tourism sector, one of the key industry sectors in Busan's local economy.

In addition, under a new TVET policy of "promoting innovation in vocational education through Meister schools", the government transformed 21 existing TVET schools into Meister high schools (contingent upon meeting performance criteria). In 2013, the number of Meister high schools expanded to 40, and $90.3 \%$ of the total number of graduates $(3,375)$ were employed (KRIVET, 2014, p. 3). The purpose of establishing the Meister high school is to produce skilled workers via a curriculum tailored to industry needs in order to reduce skills mismatching (Park, 2014). Also, by distinguishing Meister high schools from specialized high schools (TVET) and including them in the group of special purpose high schools whose aim is to produce the 'best of the best' in a specific career field, the government proposed to reduce the TVET stigma attached to Meister high schools and attract more talented students. Moreover, to promote Meister high schools, the government provided Meister high schools with financial resources to substitute their students' tuition, dormitory, and fees, as well as to maintain training facilities and equipment. The schools were also given the autonomy to develop customized curricula to meet the demands of companies in their relevant fields. Due to increasing school autonomy, the government encouraged the schools to select a Principal with strong management skills via public contest. Lastly, the government encouraged the industry-based Meister to train Meister high school students via school-industry cooperation (KRIVET, 2014).

\subsection{Relevant Studies}

\subsubsection{School Outcomes and Employability}

Johansson and Adams (2004) examined outcomes occurring both within the school system as well as in the labor market. The authors asserted that the two efficiencies, internal and external, should be measured. The former measures the relationship between inputs and outputs and what occurs within the educational and training processes. The latter measures what happens to outputs of the training process in relation to economic and social requirements, also referred to as program relevance. Because the study's interest lies in TVET schools whose role is to supply adequately skilled workers to industry, I will focus more so on external school outcomes. In this study, external outcomes will be measured via the graduate employment rate, because it shows how well 
graduates are absorbed into the labor market due to their increased employability via training and education.

Employability is not synonymous with the employment rate (Yorke, 2004, p. 410), but it does increase one's chances for gaining employment. According to Zaharim (2009), "employability skills are a set of skills, knowledge and attributes that are likely to make individuals gain, maintain and excel in employment; obtain new employment; move between roles within the same organization and to get promotions" (Ismail \& Mohammed, 2014, p. 75). In addition to these skills, career management skills were included among employability skills, and personal circumstances were considered in Hillage and Pollard (1998)'s definition of employability. According to the authors, employability is composed of four main elements, which include a person's employability assets (knowledge, skills and attitudes); career management skills (job search skills); job acquirement skills (CV effectiveness, work experience and interview techniques); and personal circumstances (family responsibilities and external factors).

\subsubsection{Teachers, Curricula, Leadership, School-Industry Linkages}

\section{1) Teachers}

In general, vocational school teachers are those who train students in school rather than the work place. In some countries, vocational teachers also provide additional services (e.g. career counseling) to their students, and in other countries, like France, these additional services are not offered, as teachers are encouraged to solely focus on subject instruction (Grollmann, 2008, pp. 536-537). Whether additional services are included or not, vocational teachers should provide both general and specific skills/knowledge to their students. According to Grollmann (2008), with rapidly changing skills, there has been a demand for "a high level of holistic knowledge, competencies and commitment", as well as a demand for "very specific knowledge, which is very close to technological developments and forms of knowledge that are bound to specific production processes and their organization in their respective fields of work" (p. 544).

In addition, TVET teachers are expected to provide balanced theory and practice to students, but some countries face an issue of providing practical knowledge to TVET students as their teachers lack work experience. Misra (2011) stated that "the main challenge before European countries is to maintain a balance between theory and practice requirements for VET teachers as some of them are poorly equipped to teach because they lack recent workplace experience" (p. 38).

Another concern is that in order for TVET teachers to possess updated, relevant skills and become professionals, teachers should receive continuing professional development. Nielsen (2010) highlighted that professional development may re-establish the social recognition of teachers as professionals, and the report from European Union (2009) stated that TVET teachers should be supported through not only appropriate initial preparation and qualifications but also through continuing professional development (Misra, 2011, p. 40).

\section{2) Curricula}

According to UNESCO (2009), a curriculum can be defined as "the organization of learning sequences with a view to produce specific, intended learning outcomes, whereas curriculum development is a set of practices aimed at introducing planned changes in search of better achievements" (Mouzakitis, 2010, p. 3916). Thus, curriculum development has been a primary concern for TVET policy makers and educators, and in order to improve the outcomes, both groups have emphasized the relevance of curricula. For instance, Pisapia and Riggins (1997) and Stasz (1997) asserted that "the new vocationalism calls for enhanced relevance, which is achieved when students engage in learning experiences that are situated in real-life contexts" (Numgwo et al., 2015, p. 21). Moreover, in order to bridge knowledge and the real world, curriculum integration has been given attention. According to Numgwo et al. (2015), "students engage in independent projects which aim at developing initiative, imagination and creativity...As students work on projects, they acquire knowledge and skills that are based on the subject areas (p. 21)", and integrate learning into the process based on how well the project/activity can parallel a real-world situation.

\section{3) Leadership}

Evidence suggests that school leadership affects outcomes. For example, Dutta and Sahney's (2015) study supported leadership's effect. Applying path modeling with cross-sectional survey data obtained from 306 secondary schools in New Delhi and Kolkata, India, the study indicated that principals' leadership influenced student achievement via teachers' job satisfaction.

The importance of leadership in TVET schools has been emphasized in various TVET policy papers. For example, European Centre for the Development of Vocational Training: CEDEFOP (2011) summarized that Professionalization of VET teachers for the future (2004), published by the European Centre for the 
Development of Vocational Training, addressed the importance of training TVET school leaders in order to enhance their capability to manage human resources and motivate teachers to commit to school change. In line with the above paper, according to CEDEFOP, the OECD (2005)'s report, Teachers matter: Attracting, developing and retaining effective teachers, suggested strategies to improve the quality of school leadership which is believed to be a central element in the TVET national policy plan. Furthermore, CEDEFOP introduced leadership competencies described by Australian researchers. The competencies include "the ability to communicate a vision for the organization, build successful teams and inspire staff to make a commitment to change, as well as interpersonal skills, risk-taking, team-building and analytic and decision-making skills" (p. 32).

\section{4) School-Industry Linkages}

According to Vaaland and Ishengoma (2015), Brimble and Doner (2007) suggested three types of linkages: training and education related activities; the provision of services and other consulting activities; and research-related activities. Vaaland and Ishengoma further explained these three types: training and education-related activities include student field trips to partner companies where students are provided career information (Suraweera,1985); a provision of work experience programs, such as internships (Ayarka et al., 2011); and the involvement of industrial practitioners in teaching (Suraweera, 1985, pp. 1019-1020).

Lin and Bozeman (2006) stated that students' exposure to industry during the school year supports an increase in students' future employment (Perkmann et al., 2013, p. 428). Empirical evidence supports the argument on the importance of students' exposure to industry. For example, by using survey data conducted in Tanzania, Ishengoma and Vaaland (2015) found that school-industry linkages, such as internships; industrial practitioners' teaching; and joint projects, raise the employability of students both directly and indirectly. The study's results indicated that among the linkage types, student internships were the most effective.

In addition to student benefits, the school-industry collaboration is imperative to TVET teachers' skills enhancement. For example, Misra (2011) stated that, according to ETUCE (2008, p. 31), “[extensive cooperation] is necessary for teachers in TVET to renew their professional skills through the opportunity to work in the professional field in which they teach by way of sabbatical leave." The author further stated that OECD (2009) has also highlighted the importance of school-industry collaboration in respect to teacher's skills updates and encourages teachers to update their skills by spending time at their partnership companies (p. 41).

\section{Methodology}

\subsection{Research Design}

The study suggests that four premise factors (competent teachers, relevant curricula, effective leadership, and school-industry linkages) are likely to contribute to enhancing school outcomes. Additionally, there are external factors influencing school success, called "Ecosystem factors", such as economic, social, and political conditions (Altbach \& Salmi 2011). Hillage and Pollard (1998) also included an external factor among the four primary elements of employability. The external factors include the current opportunity level within the labor market.

The study questions (1) whether or not the selected case possesses the premise factors; (2) if so, how do these factors impact school outcomes; (3) which is the determinant that mostly contributes to the enhancement of school outcomes and in what context; and (4) how can the factors be strengthened. The conceptual framework is a reverse examination of the relationship between outcomes (the graduate employment rate as an outcome indicator) and the aforementioned four premise factors. The logic is that if a school with a high graduate employment rate possesses these factors, then we could conclude that these factors are likely to enhance school performance. Therefore, the study could suggest that an excellent TVET institution produces the best school outcomes, because it (1) conserves competent teachers; (2) delivers relevant programs; (3) displays effective leadership; and (4) develops formal linkages with enterprise.

The study method is a case study. This method was used, initially, to allow for better in-depth analysis with the included explanatory-type research questions. Other reasons included the ability to trace the unit of analysis over time instead of by incidence; the facility to prevent the investigator's manipulation of setting and actual events; as well as the fact that there were too many uncontrollable explanatory variables, like external factors (Yin, 2003).

\subsection{Case Selection}

BMT was founded in 1967 by the government to supply skilled workers to Korea's newly established industry, and since then, the school has produced 28,415 graduates (as of 2015) in the field of mechanical engineering. The school became a Meister high school in 2009, and accordingly, it reorganized the program and courses into three classes of Precision Machine; three classes of Mold Design; three classes of Shipbuilding and Machine, 
and six classes of Robot Tech. The initial year of programming focuses on the National Common Basic Curriculum, while the second and third years focus on the Optional Subject Curriculum. BMT offers 210 credits during the three year, and the ratio among normal subject vs. specialist subject vs. creative subject is 38.1: 50.5: 11.4. BMT retains a large number of teachers and staff: one principal, two vice-principals, and 113 teachers. Among them, 65 teachers are specialty teachers. The majority of teachers are in their 50s (Appendix A) and the average years of experience are high in BMT (Appendix B). The average educational level of the specialty teachers is an undergraduate degree, but some of teachers (12 specialty teachers) obtained a master's degree in their respective areas of specialty.

I selected BMT, as it has reflected an outstanding employment rate among its graduates. BMT shows very high graduate employment rates particularly after being transformed into a Meister high school. Until 2009, its graduate employment rate was between $45 \%$ and $55 \%$. However, since 2010, the employment rate has increased to $83 \%$ when the school reformed its organization and programs to apply to become a Meister high school. Since 2013, when the school produced its first Meister high school graduates, the graduate employment rate has increased to above $90 \%$ ( $83 \%$ in $2010 ; 85 \%$ in $2011,89 \%$ in $2012,90.72 \%$ in $2013,90.44 \%$ in 2014$)$. About $40 \%$ of the students are hired by public enterprises and large companies, while about $50 \%$ are hired by SMEs (BMT, 2015).

\subsection{Data Collection and Procedure}

To increase its validity, the study collected data from multiple sources (BMT publications, survey, and interviews) and analysed the perceptions of both students and teachers. In particular, the data drawn from teachers' perceptions became a basis of recommendations for other institutions who seek to develop strategies to improve their internal and external efficiencies.

\subsubsection{The Survey}

The survey was conducted with students, teachers, vice principals, and the principal. For the students, I excluded $1^{\text {st }}$ grade students, as they are assumed to have a lack of learning experiences with BMT (Korea's school year starts in the first week of March, and this survey was conducted during the second week of April). Five hundred fifty-five students ( 2772 nd graders and 278 3rd graders) out of the total number of 600 (300 for $2^{\text {nd }}$ and $3^{\text {rd }}$ grade) responded to the survey. For teachers, I excluded administrative staff, because they are assumed to have no knowledge of the school's program. One hundred seven teachers responded to the survey out of the total number of one principal, two vice-principals, and 113 teachers. The questionnaires for students and teachers are shown in Appendix C and D.

\subsubsection{The Interview}

In order to acquire an in-depth analysis, the interview set-up included interviews with 10 students, 10 specialty teachers, the principal, and one vice principal. As for the student sample, five students from the second grade and five from the third grade were selected, and like the survey, first graders were excluded due to their lack of experience with BMT. In regards to the teachers' sample, teachers from various departments with differing positions, ages, academic backgrounds and years of experience were selected in order to increase the validity of the study. The teachers' queries covered the four areas (teachers, curricula, leadership, and school-industry linkages), while the students were questioned on the two areas (teachers and curricula). Regarding the exclusion of leadership, students are not involved in school management, and in terms of the linkages exclusion, the students had not completed internships yet (internships only occur during the fall semester of senior year). The interviews were a face-to-face, one-on-one style with structured, open-ended questions (Appendix E and F).

The principal, one vice principal, 10 teachers and 10 students were interviewed separately in a closed room, and 60 minutes was allotted for each session. All responses were dictated and recorded; then the raw data was coded. According to Coffey and Atkinson (1996), coding refers to condensing the bulk of data sets into analyzable units by creating categories with and from the data (p. 26). During the coding process, I created three levels of categories, namely general, intermediate, and specific (Coffey \& Atkinson, 1996, p, 48). Subsequently, several ideas and concepts emerged, as Coffey and Atkinson (1996) stated that codes, data categories, and concepts are related closely to one another (p. 27). These emerging ideas were presented in this paper as themes. After I drafted the study, I circulated it among the interviewees to obtain their consent on the findings. 


\section{Results}

\subsection{Teachers}

\subsubsection{Students' Perceptions}

BMT students believe that their teachers are highly competent. According to the survey, 415 students (75\%) perceived that teachers are generally competent by responding that they are either very satisfied $(40 \%)$ or satisfied (35\%) with their teacher.

Three themes emerged during the interview: (1) teaching experience (2) career counseling; and (3) teachers' devotion to students.

First, the students stated that the teachers are competent in both technical knowledge and teaching: the teachers perfectly demonstrate and explain how to use a specific machine. Students prefer older teachers, because these teachers have more teaching experience and are still able to transfer the latest skills to their students. In fact, the majority of BMT teachers are in their 50s.

Second, according to the students, the teachers support the job attainment process by providing career counseling. Career plans are developed via active career conversations between the teachers and students. During this process, teachers work with individual students to help them develop a career roadmap, help students locate prospective companies, and provide them with employment possibilities at those respective companies. The teachers also assist students with acquiring certificates to apply for selected company jobs.

Third, the teachers devote themselves to an individual student's progress by working closely with them after classes, on weekends and during vacation breaks. The students also shared that they are able to improve their learning outcomes because of various opportunities for one-on-one instruction when needed.

\subsubsection{Teachers' Perceptions}

I asked the teachers to assess their own competency during the survey. Ninety-eight percent of teachers regard themselves as competent teachers who possess required technical and teaching skills. Ninety-eight percent of teachers believe that the school has adequate teacher recruitment standards to select competent teachers. The survey results show that $96 \%$ of the teachers received in-service training, and among them, $59 \%$ of teachers had received more than 61 hours up to April 2015. In addition, the majority of teachers (61\%) received the training in the form of a seminar/workshop.

During the in-depth interviews, two ideas emerged: (1) the importance of in-service training and (2) the necessity of having technical instructors alongside teachers.

First, all the teachers indicated that the key element in teacher competency is technical skills, and this can be improved via in-service training. As for newly hired teachers, the school offers training (three to six months) to newly hired teachers and hires a temporary teacher to substitute in their absence. In addition, the school appoints mentors to help them improve their technical skills (3\% of BMT teachers receive in-service training in the form of formal mentoring and leadership coaching). As for experienced teachers, they are also required to update their technical skills via in-service training of 90 hours per year. They select in-service programs, either offered by the Busan Education Office, universities (e.g. Korea University of Technology), or companies. For some job-specific skills, BMT develops its own training program with approval from the Busan Education Office. The teachers complete in-service training, because program completion is reflected in the teacher's assessment, which is directly linked to rewards and incentives.

Second, the teachers pointed out the necessity of having a technical instructor who can demonstrate the operation of a specific machine and equipment to the students and continually maintain them. They stated that regular instructors do not have time to master the utilization of and maintain all the machines and equipment, particularly new ones. To overcome this issue, the Principal mentioned that the school hired five part-time instructors who co-teach with the specialty teachers. However, because there was a sense that these part-time instructors lacked responsibility, some teachers recommended that the school hire full-time technicians.

\subsection{Curricular}

\subsubsection{Students' Perceptions}

As for the question of whether or not students believe the school is adequately preparing them, in terms of skills, to find a job, $72 \%$ of the students responded "Yes", but $78 \%$ of the students said that they take additional training aside from the school's regular courses. Fifty-nine percent of the students also stated that they are planning to attend an additional training institute after graduation. 
During the interview, the students agreed that the school offers relevant programs. Two important findings should be addressed: (1) additional training required for the national certificates due to a Korean context and (2) the importance of a project-based program.

First, given the importance of national certificates in Korea, the school provides additional training courses after regular classes, over the weekend and vacation breaks, in order to help students obtain certificates, which increases the likelihood of employment. In Korea's case, the students said that during the hiring process, companies place emphasis on an applicant's certification status. Therefore, the students reported that they take additional training aside from the school's regular courses, not because they lack practical training but to prepare to attain certain national certificates.

Second, the students stated that a project-based program improves creativity, problem solving skills, learning integration, teamwork, and the ability to apply knowledge to a real-life situation. For example, BMT students formed a group and had to produce a collective outcome that could be utilized in a real-life setting. The group project was developed based upon their own ideas via active collaboration with other group members.

\subsubsection{Teachers' Perceptions}

As for the relevance of the school curriculum, $87 \%$ of the teachers said they either agree (53\%) or strongly agree (34\%), and $93 \%$ of the teachers (38\% strongly agree; $55 \%$ agree) said the school offers high quality programs. Sixty percent of the teachers said that the students still need additional training to be employed. Overall, $95 \%$ of the teachers believe that the school provides relevant teaching programs (including practical training) to produce competitive school outcomes. Furthermore, $90 \%$ of the teachers believe that the program can help students advance to higher education.

During the in-depth interview, the teachers generally agreed that the school offers industry-driven programs. The three themes identified are (1) the importance of a project-based program; (2) an emphasis on basic technical skills rather than job-specific skills; and (3) updating curricula and supplemental training materials.

First, according to the Principal, in addition to basic technical skills and cognitive skills, current industry requires creativity, problem-solving skills, and team work skills. To support these skills, the teachers highlighted the success of a project-based program that requires students to work in teams, collaborate and produce a team-based outcome at the end of the semester. (The students also agreed that this type of cohesive project is effective in terms of skills training).

Second, the teachers believe that the school should impart basic technical skills, because these skills are in highest demand on the production line in the industry sector. According to these teachers, since it is practically impossible for a school to teach actual job-specific skills, the school should focus on teaching basic technical skills that can serve as a basis for easier attainment of job-specific skills once a specific company hires a student.

Third, according to the teachers, to meet the rapid changes in industry, BMT annually reviews its curriculum and updates supplemental training materials. The Ministry of Education (MoE) in collaboration with industry develops the textbooks, as the goal of a Meister high school is to match labor with industrial demands. Each school also develops its own supplemental training materials in collaboration with about four companies in their relevant fields.

\subsection{Leadership}

Under Principal Lee's strong leadership, the school management system has been reconstructed as a "Centre-focused Department Management" system that aims to improve open communication and unity among its faculty members. Accordingly, the school holds bi-weekly meetings to discuss and share the centre's issues, including curricula, budget, and facilities; therefore, during the meetings, the teachers can better understand the total workflow across the department as well as the centres. In addition, the centre-focused management enables the school to use the budget efficiently, as the funds are allocated to each centre, and the departments within the centre share the funds overall.

The majority of teachers indicated that they are satisfied with this new school management system and leadership. In regards to leadership direction, $82 \%$ of the teachers responded that the school has a shared vision among its faculty members; $91 \%$ believe that the school leaders have consistent school policies, and $91 \%$ believe that the school leaders execute the school's guiding principles with clarity. In terms of the capacity to deal with new challenges, $92 \%$ of the teachers believe that the school leaders envisage the future and consistently look for new and innovative products, processes, and services. Eighty-two percent of the teachers responded that the school leaders have the capacity to deal with both anticipated and unexpected challenges/risks. 
During the in-depth interviews with the teachers, two themes arose: (1) Dr. Lee's strong leadership and the (2) leadership's impact on the students' motivation and confidence.

First, the teachers all agreed that Principal Lee has strong leadership qualities that contribute to the school's outcomes. This includes his incredible vision: He defined new skills required by the labor market as creativity skills, self-directing skills, and problem solving skills, and accordingly, he developed new programs to meet these demands. Several teachers referred to the school's new initiative programs as one example of the principal's strong leadership qualities, because he initiated and developed these programs to provide the students with an opportunity to acquire in-demand skills and develop their career roadmaps. A few teachers mentioned that his vision should be shared more among his faculty members, and that he needs to increase communication with his teachers. However, even these teachers said had to agree on the Principal's strong vision and leadership and their combined contribution to the school's outcomes.

Second, some teachers stated that leadership also indirectly impacts outcomes by increasing the students' motivation and confidence. Experiences during the new initiative programs, such as "Semester for Promotion of Learning Motivation", directly influence the students in improving their motivation for skills learning and job attainment. This view is supported by the students as well. During the interview, the students stated that their experiences during "Semester for Promotion of Learning Motivation" helped them find purpose in their studies and better navigate a career plan, which pushed them to work harder during the school year to achieve their goal of employment with prospective companies.

\subsection{School-Industry Linkages}

During the survey, $95 \%$ of the teachers believe that their school has built a successful partnership with companies in order to enhance school outcomes. In addition, $96 \%$ of the teachers believe that the partnership should be formal. Although it is important to develop a formal partnership, the teachers often face difficulties because of a lack of a particular company's interest. Sixty-seven percent of the teachers said the main reason for preventing the school from developing a formal partnership is company disinterest.

During the in-depth interviews with BMT teachers, the prominent themes were (1) challenges in establishing formal linkages and (2) efforts to overcome these challenges.

The teachers identified the challenges: first, SMEs are generally not interested in offering pre-employment training to students, because they do not retain adequate training places and instructors. In addition, their production lines are constantly busy to meet their own production deadlines. Second, despite the fact that a Memorandum of Understanding (MoU) transforms informal school-industry linkages into systematic cooperation, no formal system exists to support teachers in development of a MoU with companies. A MoU defines roles and responsibilities and encourages companies to participate in developing training materials and curricula as well as to provide in-company training for the students, field visit opportunities, and employment. However, the series of tasks involving the contracting of a MoU - finding prospective companies, visiting them in person to discuss a possible collaboration, and developing a MoU - are a teacher's responsibility. Third, the role of companies is still rather advisory: for example, during the School-Industry Cooperation Advisory Committee meeting, company representatives only provided "advice" on the direction of the program and curricula. Moreover, most teachers stated that work related to school-industry cooperation is not considered a priority for companies. For example, during the Committee meeting, held biannually, sometimes one-third of a company's representatives fail to attend the meeting.

However, despite these difficulties, BMT teachers stated that they have made tremendous efforts to develop MoUs with companies to achieve respective formal partnerships. Teachers from each department work closely with representatives from four target companies, based upon their relevant fields, to develop training materials. Additionally, as the companies are more interested in training their own staff for job-specific skills, BMT teachers have worked to increase the number of prearranged employers that offer internship programs throughout the school year. (Note: Internship programs are a part of the regular curricula at BMT). Overall, internships are linked with employment, and more students are now able to receive in-company training with prearranged employers.

\section{Discussion and Conclusion}

\subsection{Answering Research Questions}

\subsubsection{Testing the First Research Question-Does the Select School Possess These Premise Factors?}

The findings strongly support that BMT conserves competent teachers, delivers relevant programs, displays effective leadership, and establishes formal school-industry linkages. 
4.1.2 Testing the Second Research Question-Do the above Factors Influence School Outcomes; and If So, How?

First, BMT's teachers contribute to school outcomes both directly and indirectly. BMT teachers directly influence employment by finding jobs for their students among their respective networks. BMT teachers also indirectly influence employment via the enhanced students' employability. Similar to the components of TVET teachers' competence that the previous authors (Grollmann, 2008; Misra, 2011) described, BMT teachers possess up-to-date technical skills and knowledge as well as teach balanced theory and practice. With well-prepared teachers, students are able to improve their overall employability. Furthermore, BMT teachers provide career counselling, which clearly indicates that BMT teachers' responsibilities and efforts fall far beyond the act of mere subject instruction.

Second, BMT's curricula enhance school outcomes indirectly via the enhanced students' employability. As Pisapia and Riggins (1997) asserted the importance of "enhanced-relevance" in TVET curricula, BMT students receive relevant programs that can be transferred to real-life settings. For example, both teachers and students highlighted the usefulness of a project-based program that enhances students' creativity, problem solving skills and application to real life. This supports Numgwo et al. (2015)'s argument for the importance of an independent project. In addition, courses, textbooks, and training materials are continually reviewed and updated to meet industry needs. Then, with their improved employability, BMT students are more likely to gain employment.

Third, leadership enhances school outcomes indirectly via the provision of overall direction (enhanced teacher competencies, relevant programs, and school-industry linkages) and the reformation of management systems that utilize school resources more efficiently. In line with the previous authors' (Australia, 2007; ECDVT, 2004; OECD, 2005) suggested components of leadership competence, the findings show that BMT's leader has ability to manage resources efficiently, motivates teachers to make a commitment to school change, and possesses strong decision-making skills. Excellent leadership also prepares the school for future challenges and increases its ability to respond to external conditions flexibly and quickly. BMT's leader accomplishes this by developing new initiatives to respond to new external changes. Furthermore, as the BMT case illustrates, an effective leader can improve students' motivation and confidence.

Lastly, school-industry linkages influence school outcomes both directly and indirectly. The linkages directly influence the outcomes: the companies that have a MoU with the school hire BMT students via the school's recommendation process. The school recommends select students to the companies for employment upon their requests. In addition, these companies provide company-specific information to BMT teachers, and with this information, the teachers are able to assist their students in preparing for employment with a specific company. The linkages also indirectly influence the outcomes: the companies share the required skills for the current labor market and support the school in developing a curriculum that reflects their defined skills along with textbooks and training materials. They also provide in-company training to students via internship programs and opportunities for "Field Visits to Companies".

4.1.3 Testing the Third Research Question-Which Determinant Mostly Contributes to the Enhancement of School Outcomes and in What Context?

The findings suggest that a key determining factor is alterable within different contexts and times.

BMT was strongly supported by the government, as the government founded BMT in 1967 to meet a shortage of skilled workers with support from the German government as well as IBRD. The teachers stated that during this period, financial and human resources were the most important factors contributing to the school's performance, as these are basic components enabling the provision of training. Although BMT faced a lack of resources, strong government support; support from IBRD and other donor countries; and the country's policy on training practical trainers enabled them to overcome the odds.

After 1985, enrollment in higher education rapidly increased due to economic growth and social demands. Consequently, according to the teachers, all TVET schools underwent difficulties during the 1990s: most students entered academic high schools to pursue higher education and a stigma on those who studied at TVET schools prevailed. The teachers indicated that BMT's survival owes itself to leadership and alumni support. First, BMT efficiently utilized its resources in the face of a lack of financial support from the government. Second, under the goal of retaining competent students and a high graduate employment rate, the school focused on establishing school-industry cooperation with strong support from its alumni. Because of its long history, BMT had prominent alumni, such as CEOs of SMEs. Their companies provided employment, lectures, and scholarships to BMT students. In addition, the teachers not only taught but also actively worked on establishing school-industry cooperation. Therefore, the teachers said that during the 1990s when there was low demand for and a high stigma attached to TVET schools, effective leadership that provides overall direction was the most 
important factor.

During the 2000s, the government's TVET policy became a major factor influencing BMT's outcomes. In 2008, the government initiated a major policy change to the TVET system. Due to a shortage of technical skilled workers and the stigma attached to TVET schools, the government decided to establish Meister high schools by selecting 39 existing TVET schools whose performance met the criteria. Given this new policy, BMT decided to participate in the selection process and became a Meister high school. Since then, it has received strong government support, financial resources in particular. To be specific, under the new TVET policy, the school was able to maintain adequate school resources via the government's strong financial support. Second, the school was able to retain highly competent teachers via mandatory in-service training that was directly linked with teacher assessment and incentives. Third, the school was able establish its own management system, as the new policy allowed school autonomy. Fourth, the school was able to strengthen school-industry cooperation, as the new policy encourages companies to build linkages with Meister high schools and hire their graduates. In fact, when the Meister high school concept was created, the government required select large companies, such as Hyundai, and the public sector, such as Korea Hydro and Nuclear Power, to create a MoU with Meister high schools in their relevant fields, and these MoUs are still in effect today. BMT teachers stated that the school often has limited capacity to produce the best outcomes even though it retains internal efficiency. This is because school outcome is influenced more so by a country's economic situation, labor market conditions, and social demands. This is an ecosystem. Therefore, the teachers agreed that without the government's new policy that created the Meister high school concept, BMT would not have been able to rebound. Owing to this, BMT recently regained its reputation and high employment rate outcomes.

Presently, as the government supports a Meister high school on strong autonomy in the areas of curriculum development and management, teachers agreed that leadership is a key factor determining the outcomes. They recommended that schools should have a highly capable leader who has a strong vision; manages resources efficiently; encourages teachers to commit to certain goals; champions a demand-driven, tailored school curriculum; and supports meaningful school-industry cooperation.

\subsection{Lessons Learned}

First, the government should develop TVET policies that create a favorable environment surrounding TVET schools by rebranding TVET and encouraging companies to participate in school-industry cooperation. The secondary level TVET schools' capacity to produce excellent outcomes is often limited by outside factors, such as the country's economic situation, labor market conditions, and social demands. Given this context, a government's TVET policy is the key to not only the school's success but also its survival. This is evidenced by the BMT case. Even though the school made tremendous efforts to survive during the 1990s, with its state of limited capacity (as all teachers indicated), it would not have regained its reputation if the government did not institute new TVET policies. In fact, BMT produced a high graduate employment rate after transforming into a Meister high school that created a new image of TVET schools: A Meister high school cultivates the best skilled young Meisters for specific fieldwork by providing these Meisters with specialized and customized curricula. This rebranding of TVET schools reduced the stigma attached to TVET schools, and as a result, more competent students are presently enrolled in TVET schools and they hope to become young Meisters. In addition, under new TVET policies, the government encourages companies to participate in school-industry cooperation and hire Meister high school graduates; for example, large companies, such as Hyundai, and the public sector, such as Korea Hydro and Nuclear Power, established linkages with BMT via MoUs and currently hire a number of BMT graduates.

Second, the school should employ different strategies based upon time and context. This is clearly indicated by the BMT case: During the 1970s, BMT, newly established by the government with support from Germany, lacked financial and human resources. Therefore, during this time, the school's major concern was how to secure financial and human resources, the foundation of the school's training program. As BMT is a public school, its reliance on government support and policy was automatic. Korea's case illustrates that both the government and school worked together to secure resources in a manner that allowed BMT to receive financial support from IBRD and other donors, as well as deliver training to practical trainers, in a rather brief period of time. During the 1990s, when the school faced the biggest challenge of low demands for TVET schools and low government support, the school's main concern was how to retain competent students. As BMT's case shows, during this time, excellent leadership and management was important, because it enabled the school to use limited resources efficiently and effectively under a goal of retaining competent students and maintaining the employment rate. Presently, as the government strongly supports TVET schools and allows them strong autonomy, leadership is a key factor in determining school outcomes. 
Third, as the role of leadership in school outcomes has become more important, it is essential for TVET schools to have a highly capable leader. Effective leaders redirect resources, initiate new plans to respond to external changes, and inspire people with vision. Moreover, the reason for stressing the importance of leadership in recent times is that secondary TVET schools have received more autonomy in school management. This is exemplified most clearly in the Principal's role. This role in school management has become more important as he or she is able to redesign school organization, manage teachers, and influence school curricula. Another reason for the importance of leadership in recent times is that as the current ecosystem rapidly changes, schools should be able to respond to this rapid change flexibly and prepare for unexpected future challenges. In these areas, leadership plays a key role. For example, since Dr. Lee (Principal) took office, BMT has undergone a series of reformations to meet industrial needs in the current economic and labor market conditions under his direction. Specifically, under his guidance, curricula and training materials have been continually updated and several new initiative programs have been introduced. Additionally, leadership determines not only a school's outcomes but also its survival, because if a school fails to manage new challenges, they cannot remain in the training market.

Lastly, the school requires different strategies to improve school performance according to the level of education and type of provider. Both BMT and Yeungjin College conserve competent teachers, deliver relevant programs, display excellent leadership, and maintain formal school-industry linkages. However, the manner in which these factors influence outcomes and the main factor determining the outcomes differ according to the level and type of provider.

Yeungjin College, at the private, tertiary level, has more autonomy in management that enables the school leaders to change their teacher recruitment policy and performance-based payment scheme. Therefore, faculty members who are directly hired and paid by the school actively participated in the reform process and the creation of their customized programs. On the other hand, overseen by the MoE, at BMT (public, secondary level), teachers are hired by the local education office and required to hold a license accredited by the MoE. Teachers are paid based upon a seniority payment scheme, and an individual school cannot establish its own recruitment standards and payment policy. Hired and paid by the government, public, secondary TVET teachers may lack a sense of ownership within a particular school as well as motivation to participate in the school's reform process. Given the lack of a sense of ownership and motivation among teachers among secondary public providers, it is very important to have an effective leader who can motivate teachers to make a commitment to school change through a strong vision, goals, and creation of an environment that increases teacher job satisfaction.

Another difference is that in contrast to BMT, who receives financial support from the government, Yeungjin College, a private provider, has to personally secure its financial resources. In this case, the school needs to develop a financial strategy of diversifying its incoming resources, and as Yeungjin's case illustrated, diversifying incoming resources can be achieved through the expansion of enterprise collaboration. More specifically, income generation can be achieved by providing services to enterprises, such as training their employees, providing technical support, sharing machines, etc. A tertiary level TVET institution has the capacity to provide these services. After selling these services, schools reinvest to upgrade their facilities in order to attract more companies. Considering the lack of financial support from the government for tertiary private providers, it is suggested that they focus on school-industry linkages as an alternative way of increasing incoming resources.

\subsection{Study Limitations}

I acknowledge that the study may have methodological limitations in generalizability. However, the case was conducted under the Multiple-Case Study Model (Appendix G) that was adopted from Yin's (2003) concept of replication logic and analytical generalizability: "Replication logic" implies that the same method is replicated across the cases, and if the findings support our theoretical proposition, then our findings will be both compelling and robust. "Analytical generalization" occurs when inference exists between theoretical propositions and the empirical results of the case study (p. 37). So far, the two case studies (BMT and Yeungjin) under this model support the theoretical proposition. If we conduct more studies by replicating the same method and are able to arrive at common conclusions from the cases, even though the contexts of the cases differ to some extent, the findings could be generalizable.

Another limitation arises from the suggestions drawn from the teachers' perceptions. However, their perceptions could be valuable, as Boreham et al. (2002) asserted that teachers' perceptions are conceptualized and shaped by "both the subjective and the objective", and "[their] Practice was reconstructed through the analysis of the teachers' process knowledge of vocational education and their professional culture." (Grollmann, 2008, p. 541). 
BMT teachers' perceptions and voices cannot be ignored as they may have formed their views during a period that was based on the interaction between their own knowledge and immediate environment or culture. Therefore, despite limitations, the findings from the study could be useful to TVET institutions and governments that have undergone a reform process to enhance school performance and overcome the issue of skills shortages.

\section{References}

Altbach, P. G., \& Salmi, J. (2011). Introduction. In P. G.Altbach,\& J. Salmi (Eds.), The Road to Academic Excellence: The Making of World-Class Research Universities (pp. 1-8). Washington D.C.: World Bank. DOI: https://doi.org/10.1596/9780821388051_INTRO

BMT. (2015). Education Planning of 2015. Busan: BMT.

CEDEFOP. (2011). Exploring leadership in vocational education and training. (Working Paper No. 13). Retrieved from European Centre for the Development of Vocational Training website: http://www.cedefop.europa.eu/en/publications-and-resources/publications/6113

Coffey, A., \& Atkinson P. (1996). Making Sense of Qualitative Data. Thousand Oaks: Sage Publications.

Dutta, V., \& Sahney, S. (2015). School leadership and its impact on student achievement: The mediating role of school climate and teacher job satisfaction. International Journal of Educational Management, 30 (6), 941-958. https://doi.org/10.1108/JJEM-12-2014-0170

Grollmann, P. (2008). The quality of vocational teachers: Teacher education, institutional roles and professional reality. European Educational Research Journal 7 (4), 535-547. https://doi.org/10.2304/eerj.2008.7.4.535

Hillage, J., \& Pollard, E. (1998). Employability: Developing a framework for policy analysis. London: Department for Education and Employment. Retrieved from http://hdl.voced.edu.au/10707/10058

Ishengoma, E., \& Vaaland, T. I. (2015). Can university-industry linkages stimulate student employability? Education and Training, 58 (1), 18-44. https://doi.org/10.1108/ET-11-2014-0137

Ismail, S., \& Mohammed, D.S. (2015). Employability skills in TVET curriculum in Nigeria federal universities of technology. Porcedia - Social and Behavioral Sciences, 204 (2015), 73-80. https://doi.org/10.1016/j.sbspro.2015.08.111

Johanson, R. K., \& Adams. R. V. (2004). Skills development in Sub-Saharan Africa. Washington D.C.: World Bank. https://doi.org/10.1596/0-8213-5680-1

KRIVET. (2014). Meister high schools' policy performance analysis and recommendations. Seoul: KRIVET.

Lee, J. H., \& Hong, S. C. (2014). 2013 Modularization of Korea's development experience: The development of vocational high schools in Korea during the industrialization period. Seoul: KDI School. Retrieved from https://www.kdevelopedia.org/resource/view/04201405130131827.do

Misra, P. K. (2011). VET teachers in Europe: polices, practices and challenges. Journal of vocational Education \& Training, 63(1), 27-45. https://doi.org/10.1080/13636820.2011.552732

Mouzakitis, G. (2010). The role of vocational education and training curricular in economic development. $\begin{array}{llll}\text { Porcedia-Social and } & \text { Behavioral 3914-3920. }\end{array}$ https://doi.org/10.1016/j.sbspro.2010.03.616

Numgwo, A. B. et al. (2015). Curriculum integration in vocational and technology education: Implication for teaching and learning. International Journal of Vocational Education \& Training, 23 (2), 15-27.

Park, D.Y. (2011). Korean policies on secondary vocational education: Efforts to overcome skills mismatch and labor force shortage. Vocational Training in Research and Practice. BWP 3/2011, 30-33. Retrieved from https://www.bibb.de/veroeffentlichungen/en/bwp/show/6663

Perkmann, M. et al. (2013). Academic engagement and commercialisation: A review of the literature on $\begin{array}{lllll}\text { university-industry relations. Research } & \text { Policy, } & 42 & \text { (2013), }\end{array}$ https://doi.org/10.1016/j.respol.2012.09.007

Vaaland, T. I., \& Ishengoma, E. (2015). University-industry linkages in developing countries: Perceived effect on innovation. Education and Training, 58 (9), 1014-1040. https://doi.org/10.1108/ET-07-2015-0067

Yin, R. K. (2003). Case Study Research: Design and Methods. ( ${ }^{\text {rd }}$ ed). Thousand Oaks: Sage Publications.

Yorke, M. (2004). Employability in the undergraduate curriculum: Some student perspectives. European Journal of Education, 39 (4), 408-427. https://doi.org/10.1111/j.1465-3435.2004.00194.x 


\section{Notes}

Note 1. This article was modified from the original case study, Case study of an excellent TVET institution: Busan meister technical high school (2016), conducted at the World Bank with the support of the Korea-World Bank Partnership Facility Grant to promote job creation and skills development in the East Asia region.

Note 2. Two cases were selected under the Multiple-Case Study Model: Busan National Mechanical Technical High school and Yeungjin College that have supplied workers to the manufacturing sector, which has been a key engine in Korea's economic growth.

\section{Appendix A}

\section{BMT teachers' age distribution (total 116)}

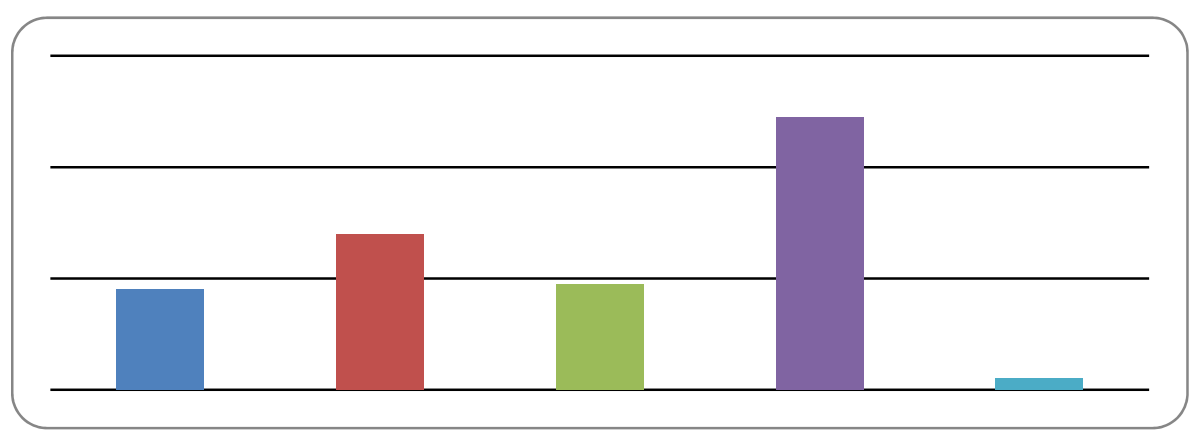

Source: Educational Planning of 2015, BMT

\section{Appendix B}

BMT teachers' year of teaching experience (total 116)

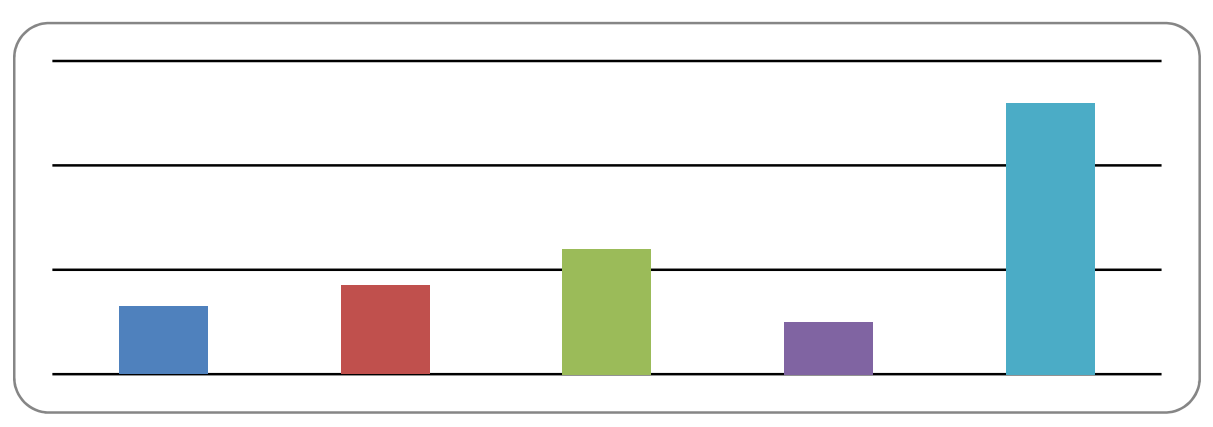

Source: Educational Planning of 2015, BMT

\section{Appendix C}

\section{Survey Questionnaire for Students}

1. Why did you select the technical or vocational track?
1) Lack of financial support from parents
2) Low school achievement (test scores, GPA)
3) Preference to be employed after secondary graduation
4) Parents' advice
5) Teacher's advice
6) Other

2. Why did you select this particular school?

1) My test scores and GPA

2) Personal interest

3) School's high graduate employment rate

4) Parents' advice

5) Teacher's advice 
6) other

3. Do you have any certifications?

1) $\mathrm{Yes}=>$ go to $\mathrm{Q} 3.1$

2) No

3-1.How many certifications do you have?

4. Upon graduation, do you plan to pursue an advanced degree?

1) $\mathrm{Yes}=>$ go to $\mathrm{Q} 4.1$

2) $\mathrm{No}$

4.1. Select desired level.

1) 4-year university

2) Graduate school

5. Upon graduation, do you plan to find a job?

1) Yes $=>$ go to Q5.1 -5.3

2) No

5.1 What size companies interest you?

1) Large company

2) Upper middle size company

3) Small and middle size company

5.2 What position level are you seeking?

1) Entry level

2) Low level skilled position

3) Middle level skilled position

4) High level skilled position

5.3 What is your expected salary? (USD)

1) Less than 1,000

2) $1,000-1,500$

3) $1,500-2,000$

4) Greater than 2,000

6. Please respond to the following phrases utilizing a response from the ratings below. Select the rating that most clearly and honestly reflects your opinion:
a. Classroom conditions
b. Computer labs/Computer access
c. Library
d. Recreation facilities
e. Practical training resources (facilities, equipment, machines, etc)
f. School programs (curricular and after school programs)
g. Career counseling
h. Teachers
i. General school life

\begin{tabular}{|l|l|l|l|l|}
\hline Very dissatisfied & Dissatisfied & $\begin{array}{l}\text { Neither satisfied nor } \\
\text { dissatisfied }\end{array}$ & Satisfied & Very satisfied \\
\hline
\end{tabular}

7. To what extent do a scholarship and/or any other financial support cover your course fees, residential costs, academic materials, etc.?
1) All
2) Most
3) Some
4) None

8. Do you receive career counseling?

1) $\mathrm{Yes}=>$ go to $\mathrm{Q} 8.1$

2) $\mathrm{No}$

8.1 Is the counseling helping you navigate your career plans?

1) Yes

2) No 
9. How many hours per week do you receive practical training at school?

1) Less than 10

2) $11-15$

3) $16-20$

4) More than 20

10. Do you think the school is preparing you adequately, skill-wise, to find a job?

1) Yes

2) $\quad$ No $=>$ go to Q10.1 and 10.2

10.1. Did you receive additional training, aside from in-school practical training?

1) $\mathrm{Yes}=>$ go to $\mathrm{Q} 10.1 .1$

2) No

10.1.1. How many hours per week do you train?

1) Less than 10

2) $10-15$

3) $16-20$

4) Greater than 20

10.2 Are you planning to receive additional training from a training institute after graduation?

1) Yes

2) No

(C) Copyright 2016 by Lan Joo

\section{Appendix D}

\section{Survey Questionnaire for Teachers}

1. Do you think the school provides adequate financial support to your students?

1) $\mathrm{Yes}=>$ go to $\mathrm{Q} 1.1$

2) No

1.1. Do you think providing financial support plays a primary role in attracting talented students?

1) Yes

2) No

2. Please respond to the following phrases utilizing a response from the ratings below. Select the rating that most clearly and honestly reflects your opinion:

a. School building conditions, including the practical training facility

b. Equipment maintenance

c. Retaining full and updated equipment

\begin{tabular}{|l|l|l|l|l|}
\hline Excellent & Good & Fair & Bad & Poor \\
\hline
\end{tabular}

3. Does the school have a support system to assist students with their career plans (e.g. a job service center)?

1) $\mathrm{Yes}=>$ go to $\mathrm{Q} 3.1$

2) No

3.1. Please rate the existing support system:

\begin{tabular}{|l|l|l|l|l|}
\hline Excellent & Good & Fair & Bad & Poor \\
\hline
\end{tabular}

4. Do you assist students in career development?

1) Yes

2) No

5. In your opinion, which is the most important criterion in recruitment of a competent teacher?

1) Minimum academic qualifications (certificates, diplomas, and degrees)

2) Minimum years of industry or work experience

3) Minimum years of teaching experience

4) Other 
6. Do you think that your school's recruitment standards for teachers are adequate enough to select competent teachers who will improve the employability of the student population?

1) Yes

2) $\quad$ No $=>$ go to Q 6.1

6.1 Please explain why the standards are not adequate

7. Did you complete in-service training?

1) $\mathrm{Yes}=>$ go to $\mathrm{Q} 7.1-7.3$

2) No

7.1. Select type(s) of training.

1)

2)

3)

4)
Seminars, workshops, and conferences

Formal courses

Formal mentoring and leadership coaching

Other

7.2. How many hours per year did you complete?

1)Less than 10

2) $10-15$

3) $16-20$

4) Greater than 20

7.3. Did you receive the training from companies contracted by the school?
1) Yes
2) No

8. Are you a competent teacher; do you possess the required teaching skills set?

1) Yes

2) $\mathrm{No}=>$ go to Q.8.1

8.1. What missing skills would increase your competence?

1) More academic knowledge

2) More practical training

3) More work experience

4) More teaching experience

5) Other

9. Please rate your relationship with your students:

\begin{tabular}{|l|l|l|l|l|}
\hline Excellent & Good & Fair & Bad & Poor \\
\hline
\end{tabular}

10. All in all, does the school have adequate financial and human resources to produce competitive school outcomes (e.g. the graduate employment rate)?
1) Yes
2) No

11. Please respond to the following statements utilizing a response from the ratings below. Select the rating that most clearly and honestly reflects your opinion:

a. The school curriculum (both academic and practical) reflects current industry demands.

b. The school offers high quality programs (both academic and practical programs).

c. My students need to take additional outside training to be employed.

d. My students enjoy their studies. 
e. My students are highly competent.

\begin{tabular}{|l|l|l|l|l|}
\hline Strongly Agree & Agree & $\begin{array}{l}\text { Neither Agree nor } \\
\text { Disagree }\end{array}$ & Disagree & Strongly Disagree \\
\hline
\end{tabular}

12. Does the school offer academic programs to students who want to continue their education/pursue an advance degree?

1) $\mathrm{Yes}=>$ go to $\mathrm{Q} 12.1$

2) No

12.1. Do you think this program helps students advance to higher education?

1) Yes

2) No

13. All in all, does the school provide relevant teaching programs (including practical training) to produce competitive school outcomes (e.g. the graduate employment rate)?
1) Yes
2) No

14. Please respond to the following statements utilizing a response from the ratings below. Select the rating that most clearly and honestly reflects your opinion:

a. My school leaders have consistent school policies.

b. My school leaders execute the school's guiding principles with clarity.

c. My school leaders are consistent about their words and deeds.

d. My school leaders envisage the future and consistently look for new and innovative products, processes, and services.

e. My school leaders encourage collaboration by building trust among faculty members.

f. My school leaders encourage self-determination and the developing competence of teachers.

g. My school leaders recognize my contribution by showing appreciation.

h. The school has a shared vision among their faculty and staff.

i. The school has the capacity to deal with both anticipated and unexpected challenges/risks.

j. The school is attracting highly competent students.

\begin{tabular}{|l|l|l|l|l|}
\hline Strongly agree & Agree & $\begin{array}{l}\text { Neither agree nor } \\
\text { disagree }\end{array}$ & disagree & Strongly disagree \\
\hline
\end{tabular}

15. Please rate the relationship

a. between you and the principal

b. between you and other teachers

\begin{tabular}{|l|l|l|l|l|}
\hline Excellent & Good & Fair & Bad & Poor \\
\hline
\end{tabular}

16. Do you believe that a school should build a formal partnership with companies?

1) $\mathrm{Yes}=>$ go to $\mathrm{Q} 16.1$

2) No

16.1. Please explain why

17. If your school does not have a formal partnership, what barriers will the school encounter in forming the partnership?

1) The school is not interested in a formal linkage.

2) The school desires a linkage but lacks the capacity.

3) The companies are not interested. 


\section{4) Other}

18. Do you believe that your school has built a successful partnership with companies in order to enhance school outcomes e.g. graduate employment rate?
1) Yes
2) No

19. To what degree has the government's TVET policies impacted your school's governance and policies?
1) All
2) Most
3) Some
4) None

20. Do you think Leadership at the National Level has consistent policies?

1) Yes

2) No

21. Do you think the government adequately articulates the policy on TVET collaboration (e.g. collaboration type, building methods, students' rights) and develops laws for this?
1) Yes
2) No

22. Do you think government financial mechanisms (e.g. incentives) help enhance school performance?

1) Yes

2) No

23. Practically speaking, are your students readily able to advance their education e.g. from a technical/vocational high school to college?
1) Yes
2) No

(C) Copyright 2016 by Lan Joo

\section{Appendix E}

\section{Interview Questions for Students}

1. Why did you select this particular school? What were your expectations?

2. Are you satisfied (or dissatisfied) with your choice of this school? Please provide details in regards to the curriculum, facilities, teachers, etc.

3. Do you believe that your school is a top performing institution? Please explain why/why not.

4. Upon graduation, are you planning to pursue higher education or enter the labor market? Explain your decision.

5. In regards to career, what desired level do you aspire to secure on hire?

6. Do you think it is necessary to earn a university diploma to acquire this desired job?

7. Do you think the school provides adequate practical training in order to secure a job? If yes, please describe. If not, what are the primary challenges?

8. Do you believe that your school is helping you build your future career plans? Who helps you the most? How do they help you?

9. Do you think the school stimulates and supports your creative development? If so, please describe any existing programs and how they stimulate your creativity. If not, what are the primary challenges?

(C) Copyright 2016 by Lan Joo 


\section{Appendix F}

\section{Interview Questions for Teachers}

1. Define "an excellent school".

2. In your opinion, what factors are attributed to your defined "excellent school"? How and why do they impact school outcomes, e.g. graduate employment rates?

3. Do you believe that your school has adequate resources (both financial and human) to enhance the employability of your students?

4. Do you believe that your school's resources (both financial and human) are efficiently utilized?

5. Do you believe that the school provides the most relevant and updated skills to enhance student employability?

6. Do you believe that your school is a well-managed school in terms of leadership and governance?

7. Do you believe that your school has strong enterprise partnerships in the areas of resources, teaching, and management?

8. Among the previous four factors, which factor had the highest impact on the success of schools (high employment rates of your students)? Provide an example within a specific context and time.

9. Based on personal experience, what are your suggestions on how to improve your identified factor?

10. How has your school successfully overcome both internal and external challenges? Provide an example within a specific context and time.

11. In your opinion, to what degree has the government's TVET policies impacted your school's governance and policies? Explain how.

(C) Copyright 2016 by Lan Joo

\section{Appendix G}

\section{Multiple-Case study Design}

\section{Theoretical Proposition}

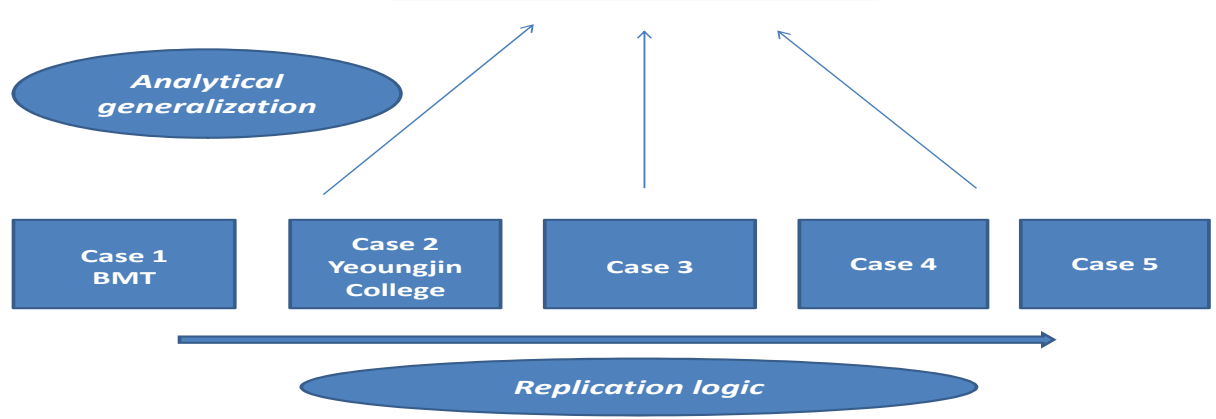

Source: Modified from “Case Study Research”, Yin, 2003

\section{Copyrights}

Copyright for this article is retained by the author(s), with first publication rights granted to the journal.

This is an open-access article distributed under the terms and conditions of the Creative Commons Attribution license (http://creativecommons.org/licenses/by/4.0/). 